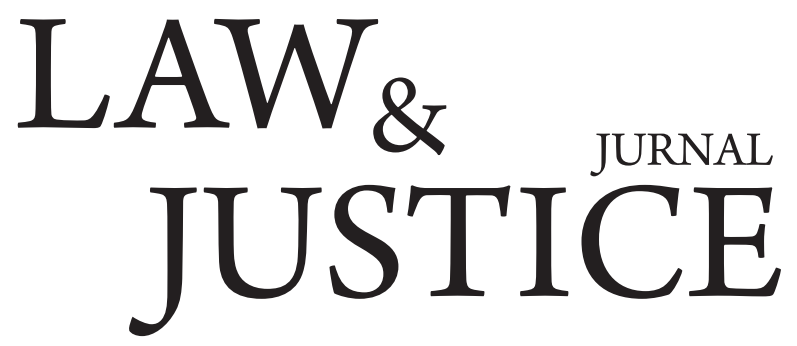

\title{
Menggagas Mekanisme Preventive Review Oleh MK, Upaya Percepatan Pembangunan Nasional Melalui Produk Hukum Berkualitas
}

\author{
Dimas Firdausy Hunafa \\ Program Pascasarjana Magister Ilmu Hukum Fakultas Hukum Universitas Islam Indonesia \\ Jalan Cik Di Tiro No. 1, Gondokusuman, Kota Yogyakarta, Daerah Istimewa Yogyakarta 55223 \\ Email: dimasf1010@gmail.com
}

\begin{abstract}
Abstrak
Produk hukum yang berkualitas merupakan kebutuhan paling penting dalam proses pembangunan Nasional Negara Indonesia sebagai sarana pembangunan dalam berbagai lini dapat tercapai. Namun selama ini, banyaknya produk hukum yang diuji oleh Mahkamah Konstitusi (MK) mengisyaratkan bahwa produk hukum yang dibuat oleh legislatif dan eksekutif masih belum bisa dikatakan berkualitas. Diperlukan penguatan dan sinergitas produk hukum dengan konstitusi atau Undang-Undang Dasar 1945 (UUD 1945). Hal ini, dapat diupayakan melalui cabang kekuasaan kehakiman, yaitu dengan adanya mekanisme preventive review oleh MK. Istilah preventive review pada dasarnya, merupakan suatu mekanisme pengujian konstitusionalitas rancangan undang-undang (RUU) di MK yang nantinya akan menguji RUU sebelum disahkan dan diberlakukan. Sehingga, MK sebagai pengawal konstitusi memberikan kontribusi preventive bagi setiap produk hukum peraturan perundang-undangan yang dibuat, agar kiranya dapat sejalan dengan cita konstitusi dan melahirkan produk hukum yang berkualitas. Penelitian ini merupakan penelitian doktrinal yang menggunakan bahan hukum primer dan bahan hukum sekunder. Metode yang digunakan yakni yuridis-normatif dengan menggunakan pendekatan undangundang dan konseptual. Hasil penelitian ini setidaknya memberikan kesimpulan bahwa terdapat urgensi penambahan kewenangan preventive review oleh Mahkamah Konstitusi. Dimana, jika mekanisme ini diterapkan, maka produk hukum yang dibuat diharapkan dapat sejalan dengan cita konstitusi sehingga melahirkan produk hukum yang berkualitas yang kemudian dapat menunjang dan mempercepat proses pembangunan di Negara Indonesia tercapai.
\end{abstract}

Kata kunci: produk hukum berkualitas, preventive review, pembangunan nasional 


\section{Pendahuluan}

Berbicara mengenai pembangunan nasional, ${ }^{1}$ tentu saja didalamnya terdapat multi aspek yang dibahas, termasuk pembangunan hukum di Indonesia, dapat dikatakan, hukum adalah "rel" untuk mencapai tujuan (pembangunan nasional) itu baik dalam segi ekonomi, pendidikan, budaya, sosial, dan lain sebagainya, karena melalui hukum, segala bentuk kegiatan di negara Indonesia dapat dijalankan. ${ }^{2}$ Pada sisi yang lain, ditengah masyarakat yang selalu berkembang secara dinamis akibat pengaruh digitalisasi yang ditandai dengan era baru dalam bidang teknologi dan komunikasi serta industrialisasi belakangan ini, produk hukum yang berkualitas menjadi urgen untuk dihadirkan. Hal ini bertujuan untuk dapat terus menjawab tekanan dan tantangan kedepan akibat restrukturisasi cara hidup umat manusia secara mendalam. Dengan demikian, hukum tidak boleh bersifat statis sebagaimana ungkapan Mochtar Kusuma Atmadja, ${ }^{3}$ mengenai arti dan fungsi hukum bagi peradaban manusia secara kolektif yang sedang mengalami proses membangun. Menurutnya, hukum tidaklah

1 Di Indonesia, rencana pembangunan nasional dapat ditemukan dalam Rencana Pembangunan Jangka Panjang Nasional (RPJPN 2005-2025). Sistem ini merupakan pengganti GBHN yang diberlakukan sejak tahun 2005. Tulisan ini akan membahas keterkaitan "hukum dan pembangunan" dalam konteks ketatanegaraan di Indonesia. asumsi dasar yang di-konstruksikan dalam pemikiran penulis ialah, pembangunan tidak terbatas pada aspek ekonomi semata, namun dari semua aspek yang bersentuhan dengan sosial kemasyarakatan baik ekonomi, budaya, sosial, teknologi, termasuk pembangunan hukum yang satu sama lain saling berkelindan, jika semua aspek pembangunan itu berjalan dengan baik, maka keteraturan pembangunan yang dicita-citakan makan berjalan sebagaimana mestinya. Sebagai negara yang mendasarkan pada aturan hukum, aspek pembangunan hukum di Indonesia memiliki peran penting. Dimulai dari regulasi atau produk hukum peraturan perundangundangan.

2 Sebagaimana Negara Indonesia telah meneguhkan dirinya berdasarkan atas hukum, Pasal 1 Ayat (3) UUD Negara Republik Indonesia Tahun 1945 (Pasca Amandemen) tegas dikatakan, Negara Indonesia adalah negara hukum. Memiliki arti, segala tingkah kehidupan berbangsa dan bernegara diatur berdasarkan atas hukum yang berlaku.

3 Mochtar Kusumaatmadja, Fungsi Dan Perkembangan Hukum Dalam Pembangunan Nasional, Lembaga Penelitian Hukum dan Kriminologi, Fakultas Hukum Universitas Padjadjaran, (Bandung: Penerbit Binacipta, 1970), hlm. 11. sekedar alat, alat dalam arti memiliki fungsi memelihara ketertiban dalam masyarakat dan memepertahankan apa yang telah tercapai. Namun hukum adalah sarana, dengan begitu hukum tidaklah statis, melainkan dinamis dan sejatinya hukum tidak cukup memiliki fungsi demikian saja, hukum harus mampu membantu proses perubahan masyarakat itu.

Bagi Negara Indonesia, suatu produk hukum dapat dikatakan berkualitas apabila produk hukum tersebut selaras dengan Konstitusi atau UUD 1945 yang merupakan jantung Negara Republik Indonesia (NRI). Konstitusi sebagaimana kita ketahui, merupakan rangkuman hukum dasar yang dijadikan pegangan dalam penyelenggaraan negara. Konstitusi dapat berupa hukum dasar tertulis dan dapat pula tidak tertulis. ${ }^{4}$ UUD 1945 sebagaimana telah diubah beberapa kali yaitu pada tahun 1999, 2000, 2001 dan 2002 merupakan kesatuan rangkaian perumusan hukum dasar Indonesia di masa depan. Isinya mencakup dasardasar normatif yang berfungsi sebagai sarana pengendali (tool of social and political control) terhadap penyimpangan dan penyelewengan dalam dinamika perkembangan zaman sekaligus sarana pembaharuan masyarakat (tool of social and political reform) serta sarana perekayasaan (tool of social and political engineering) ke arah cita-cita kolektif bangsa. ${ }^{5}$ Untuk itu dalam rangka mencapai cita-cita tersebut, harus dibarengi dengan pembangunan nasional baik dalam segi ekonomi, pendidikan, budaya, sosial, dan lain sebagainya agar kesejahteraan masyarakat benar-benar dapat dirasakan.

Namun belakangan ini, tidak sedikit produk hukum yang dihasilkan oleh lembaga legislative atau pembuat undang-undang dinilai inconstitutional oleh MK, sehingga berpotensi menghambat proses pembangunan di Indonesia karena pijakannya yang tidak bermutu. Selama ini, Produk hukum yang dinilai bertentangan dengan konstitusi NRI dapat diuji oleh MK sebagai pelaku kekuasaan kehakiman dalam hal penyelenggaraan peradilan yang berfungsi menegakkan hukum dan keadilan. Tidak jarang MK menyatakan sebuah undang-undang (atau beberapa pasal dalam undang-undang) dianggap inconstitutional atau bertentangan dengan UUD 1945 yang diajukan

\footnotetext{
4 Jimly Asshiddiqie, Konstitusi dan konstitusionalisme, Cetakan Keempat (Jakarta: Sinar Grafika, 2017), hlm. 29

$5 \quad$ Ibid., hlm 30.
} 
oleh para pemohon. Sepatutnya, hukum yang lebih rendah harus berdasar, bersumber dan tidak boleh bertentangan dengan hukum yang lebih tinggi derajatnya, ini mengacu pada stufenbautheory-nya Hans Kelsen.

Mekanisme yang demikian dikenal dengan istilah judicial review, dimana mekanisme pengujian undang-undang baru dapat dilakukan bilamana produk hukum peraturan perundangundangan telah mendapat persetujuan oleh organ negara (eksekutif), dan telah diterbitkan melalui lembaran negara, namun setelah undang-undang tersebut berlaku pada suatu waktu dianggap bertentangan dengan konstitusi atau UUD 1945, dimana mekanisme yang demikian dapat dikatakan sebagai model pengujian represive dan apabila MK kemudian menyatakan undang-undang tersebut bertentangan dengan UUD 1945 maka dapat disebut dengan inconstitutional represive. ${ }^{6}$ Pada satu sisi, mekanisme yang demikian pada saat ini dirasa masih kurang karena dengan hanya melakukan pengawasan terhadap peraturan perundang-undangan yang sudah berlaku, faktanya hanya akan memperlambat proses pembangunan itu sendiri karena prosedurnya yang begitu lama.

Dihadapkan pada tantangan globalisasi modern, reformasi dan penyempurnaan sistem hukum serta konstitusi mutlak direalisasikan, hal ini merupakan prasyarat untuk membangun negara demokrasi konstitusional (constitutional state) di Indonesia. ${ }^{7}$ Langkah-langkah reformasi hukum tidak hanya dimulai dengan mereformasi substansi hukum (legal substance), seperti perbaikan kualitas perundang-undangan dan peraturanperaturan hukum lainnya, namun juga harus diikuti dengan perbaikan institusi kekuasaan kehakiman sebagai struktur hukum (legal structures). ${ }^{8}$ Dengan reformasi substansi dan struktur hukum yang berkelanjutan, yang nantinya akan terus mendorong pembangunan diberbagai lini tetap terus berjalan.

Saat ini yang diperlukan ialah suatu model baru dalam mengawasi peraturan perundang-

6 Muhammad Reza Maulana, "Upaya menciptakan Produk Hukum Berkualitas Kontitusi Melalui Model Preventif Review", Jurnal Konstitusi, Edisi No. 4 Vol. 15, (2018), hlm 780.

7 Dan Josua Satria Collins dan Pan Mohammad Faiz, "Penambahan Kewenangan Constitutional Question Di Mahkamah Konstitusi Sebagai Upaya Untuk Melindungi Hak-Hak Konstitusional Warga Negara", Jurnal Konstitusi, No 4 Vol 15, (2018), hlm 690.

$8 \quad$ Ibid., hlm. 690 undangan yakni melalui mekanisme preventive review, dimana peraturan perundang-undangan yang baru (RUU) yang dibuat oleh lembaga legislatif maupun eksekutif, akan di review terlebih dahulu oleh lembaga yudikatif (MK) sebelum disahkan, sehingga peraturan tersebut tidak lagi banyak mengalami ketimpangan terhadap konstitusi yang ada ketika nanti telah diterapkan (diberlakukan). Harapannya, proses pembangunan nasional diberbagai aspek tidak lagi terganggu.

Penulisan penelitian ini bertujuan untuk mengetahui bagaimana mekanisme preventive review oleh MK dalam memberikan kontribusi terhadap pembuatan peraturan-perundangundangan sebagai upaya untuk melahirkan suatu produk hukum yang berkualitas, dan apa dampaknya terhadap proses pembangunan nasional itu sendiri. Serta, penulis ingin menjawab pokok permasalahan mengenai seberapa besar urgensi penerapan mekanisme preventive review di Indonesia. Pembahasan terhadap isu tersebut kemudian akan dibagi ke dalam dua bagian, pertama, urgensi penerapan mekanisme preventive review dalam sistem peradilan konstitusi (MK) dan analisis manfaat penerapannya terhadap pembangunan nasional. kedua, menakar peluang penerapan mekanisme preventive review dalam sistem ketatanegaraan Indonesia.

\section{Metode Penelitian}

Penelitian ini merupakan salah satu bentuk penelitian yuridis-normatif dengan pendekatan undang-undang dan konseptual. Teks peraturan perundang-undangan hanya dipergunakan untuk menjustifikasi terhadap objek kajian. Dalam menjabarkan pokok permasalahan, mengacu pada kerangka teori yang ada dan dikontekskan pada konsepsi negara hukum Indonesia dalam menjawab persoalan dalam penelitian ini.

\section{Analisis/ Pembahasan}

\section{Urgensi Penerapan Mekanisme Preventive Review}

Dalam perjalanannya, reformasi yang berjalan kurang lebih dalam kurun waktu 2 (dua) dekade ini, menghasilkan empat kali perubahan UUD 1945 yang telah membawa nuansa baru dalam sistem ketatanegaraan Indonesia. Sinyal reformasi tersebut memberikan harapan besar bagi 
terciptanya perubahan menuju penyelenggaraan negara yang demokratis, transparan, dan memiliki akuntabilitas tinggi, serta terwujudnya good governance. ${ }^{9}$ Perubahan UUD 1945 diperlukan untuk menyesuaikan dengan mengikuti perkembangan kebutuhan masyarakat yang begitu dinamis, perubahan yang berlaku diberbagai sektor seperti sektor budaya, politik, ekonomi, pendidikan, hukum dan lain sebagainya, dengan mendasarkan konstitusi sebagai hukum tertinggi yang didalamnya mengandung nilai (values) yang berlaku di masyarakat.

Selain itu, sebagai negara yang meletakkan kedaulatannya di tangan rakyat ${ }^{10}$ dan meneguhkan dirinya sebagai negara hukum ${ }^{11}$ yang bernafaskan demokrasi, memiliki arti bahwa Negara Indonesia diperintah atas dasar hukum yang berlaku, termasuk kepala pemerintahan pun harus tunduk kepada hukum yang berlaku tersebut. Dengan demikian, keberadaan hukum di Indonesia juga dapat disebut sebagai sarana mewujudkan cita-cita kolektif bangsa sebagaimana tujuan itu tertuang dalam Pembukaan UUD 1945, setidak-tidaknya ada empat point utama yakni, pertama, melindungi segenap bangsa Indonesia dan seluruh tumpah darah Indonesia, kedua, memajukan kesejahteraan umum, ketiga, mencerdaskan kehidupan bangsa, dan keempat, ikut melaksanakan ketertiban dunia yang berdasarkan, kemerdekaan, perdamaian abadi dan keadilan sosial. ${ }^{12}$

Aristoteles ${ }^{13}$ mengatakan bahwa, hadirnya negara karena memiliki tujuan menyelenggarakan hidup yang baik terhadap warganya, tentu saja tujuan tersebut yang kemudian dirumuskan dalam tujuan pembangunan sebagaimana dicita-citakan oleh konstitusi, keberadaan hukum menjadi acuan agar tidak keluar dari koridor-koridor kepastiannya. Penjelmaan hukum sebagai sarana menunjang pembagunan nasional dapat kita rasakan dengan

$9 \quad$ Sekretariat Jenderal Majelis Permusyawaratan Rakyat Republik Indonesia, Panduan Pemasyarakatan Undang Undang Dasar Negara Republik Indonesia Tahun 1945 dan Ketetapan Majelis Permusyawaratan Rakyat republik Indonesia, Jakarta: Sekretariat Jenderal MPR RI, 2012), hlm 5.

10 Pasal 1 ayat (2) UUD Negara Kesatuan Republik Indonesia Tahun 1945 (Pasca Amandemen).

11 Pasal 1 ayat (3) UUD Negara Kesatuan Republik Indonesia Tahun 1945 (Pasca Amandemen).

12 Lihat dalam Pembukaan UUD Negara Kesatuan Republik Indonesia Tahun 1945 (alinea keempat).

13 Lihat dalam , Ni'matul Huda, Ilmu Negara, (Jakarta: Rajawali Press, 2013), hal. 54 adanya berbagai macam regulasi yang mengatur tata tertib manusia dalam masyarakat itu. Disini, menakar produk hukum yang digunakan sebagai sarana penunjang pembangunan nasional wajib diperhitungkan, melihat perannya yang sangat signifikan. Dengan lahirnya produk hukum yang berkualitas dan berkesesuaian dengan konstitusi tidak menutup kemungkinan keteraturan dan ketertiban masyarakat akan terus mendorong proses pembangunan dalam berbagai aspek dapat tercapai. Di Indonesia, menurut bentuknya hukum dibedakan menjadi dua macam jenis, yakni hukum tidak tertulis ${ }^{14}$ dan hukum tertulis. ${ }^{15}$

Meskipun terdapat aturan khusus tentang pembentukan peraturan perundang-undangan sebagaimana ketentuan tersebut dapat dilihat dalam Undang-undang Nomor 12 Tahun 2011, yang mana telah menjelaskan tentang mekanisme, tingkatan (hierarki) dan landasan-landasan yang harus diperhatikan dalam membentuk suatu peraturan perundang-undangan yang dituangkan dalam naskah akademik, kendatipun demikian pengawasan terhadap adanya undang-undang yang hanya diperuntukkan kepada sebahagian kelompok atau elit politik tertentu dengan mengesampingkan Undang-Undang Dasar 1945 dipandang penting untuk diuji oleh suatu kekuasaan yang memiliki kewenangan untuk itu, sebagai tujuan peningkatan kualitas peraturan perundang-undangan dan menyesuaikan dengan cita konstitusi Republik Indonesia tidak hanya dengan cara represive namun juga diperlukan cara preventive. ${ }^{16}$

Urgensi penerapan mekanisme preventive review dalam pembuatan produk hukum peraturan perundang-undangan dengan demikian menjadi hal yang patut untuk diatur lebih lanjut didalam kewenangan MK dengan menimbang beberapa aspek, yang pertama, sebagai bentuk pencegahan adanya undang-undang yang tidak berkualitas. Kualitas legislasi di Indonesia sering dipertanyakan ketika MK membatalkan beberapa pasal atau bahkan seluruh batang tubuh suatu undang-undang. Buruknya kualitas legislasi tersebut dipengaruhi oleh kuatnya faktor politis dalam proses legislasi. Faktor tersebut berdampak pada ketidaksinkronan undang-undang dengan

14 Hukum tidak tertulis ialah hukum kebiasaan yang berlaku dimasyarakat (customary law) dan hukum adat.

15 Hukum tertulis ialah hukum yang dibuat oleh lembaga negara yang memiiki wewenang atas itu yang dicantumkan dalam peraturan perundang-undangan.

16 Muhammad Reza Maulana, Upaya... op.cit,. hlm 789. 
konstitusi atau ketidakharmonisan undang-undang dengan undang-undang yang lain. ${ }^{17}$ Pandangan ini, tidak terlepas dengan adanya pengaruh politik transaksional didalam proses pembuatan peraturan perundang-undangan. Sehingga dalam proses pembuatan peraturan perundang-undangan seringkali disusupi oleh kepentingan-kepentingan yang dibawa oleh masing-masing kelompok yang memiliki kepentingan itu, yang terjadi kemudian produk hukum yang dihasilkan tidak terlepas dari kepentingan-kepentingan kelompok semata. ${ }^{18}$ Hal tersebut memperlihatkan bahwa hukum tidak netral dan terlepas dari politik, persis dengan yang disampaikan oleh Mahfud MD bahwa, hukum adalah produk politik. ${ }^{19}$ Alhasil, tujuan hukum yakni keadilan, kemanfaatan, dan kepastian hukum sebagamana dicita-citakan akan termanipulatif.

Sehingga dalam praktek, produk hukum yang dibuat oleh legislatif mendapat penolakan oleh berbagai kalangan termasuk rakyat si-pemilik kedaulatan, bahkan ketika produk hukum itu belum disahkan dan diberlakukan. Terlebih yang sangat dikhawatirkan oleh penulis ialah ketika produk hukum tersebut mendapat banyak penolakan, namun oleh legislatif dipaksakan untuk disahkan, disini menurut penulis terdapat triall and error dalam prosesnya.

Suatu produk hukum harus mencerminkan kepentingan dan perasaan keadilan rakyat. Karena itu, hukum harus dibuat dengan mekanisme demokratis. Hukum tidak boleh dibuat untuk kepentingan kelompok tertentu atau kepentingan penguasa yang akan melahirkan negara hukum yang totaliter. Hukum tertinggi di suatu negara adalah produk hukum yang paling mencerminkan

17 Muhammad Reza Maulana, Upaya... op.cit,. hlm 789.

18 Dalam bukunya, Bernard L Tanya, menjelaskan salah satu fungsi hukum adalah menjadi the art of values (seni mempertahankan nilai-nilai), salah satu alasan yang diajukan dalam hal ini ialah dalam realitas yang ada bahwa hukum mudah dimanupulasi (baik dari otoritas dalam maupun dari otoritas luar). Manipulasi hukum terbuka luas melalui ruang politik disebabkan hukum diproduksi secara politik. Pengambilan keputusan yang mengandalkan angka dan jumlah, sangat mudah menjadi jalan untuk memenangkan segala hal, meski akan menghancurkan republik. Habit tawar-menawar model dagang sapi di parlemen, memungkinkan semua hal buruk menyusup dalam hukum. Lihat, Yovita A. Mangesti \& Bernard L. Tanya, Moralitas Hukum, cetakan pertama (Yogyakarta: Genta Publishing, 2014), Hlm 19.

19 Moh. Mahfud MD, Politik Hukum di Indonesia, cetakan kedua, (Jakarta: PT Pustaka LP3ES, 2001), hlm 7. kesepakatan dari seluruh rakyat, yaitu konstitusi. Dengan demikian aturan dasar penyelenggaraan negara yang harus dilaksanakan adalah konstitusi. Semua aturan hukum lain yang dibuat melalui mekanisme demokrasi tidak boleh bertentangan dengan konstitusi. ${ }^{20}$ Untuk itu mekanisme preventive review ini oleh Sofia Amaral-Garcia dkk. ${ }^{21}$ mendapat perhatian, dia menyebutkan bahwa,

"Given the political importance of preventive constitutional review, these decisions are the ones in which we anticipate a higher degree of party politics".

Diharapkan proses pengujian RUU melalui mekanisme preventive review, dapat meminimalisir kekhawatiran akan hal diatas dapat terjadi, dan langkah ini kemudian dapat mengupayakan aspirasi-aspirasi yang dikehendaki oleh rakyat dapat dimaksimalkan. Proses ini adalah langkah pencegahan dini (upaya preventif) terhadap adanya kepentingan-kepentingan tersembunyi yang disisipkan melalui produk hukum peraturan perundang-undangan.

Kedua, sebagai bentuk perlindungan terhadap hak asasi warga negara. Salah satu prinsip dibentuknya lembaga MK ialah untuk melindungi hak yang melekat pada warga negara yang dijamin oleh konstitusi atau UUD 194 (hak konstitusional). ${ }^{22}$ Mengenai pengaturan dan penjaminan pengakuan hak asasi manusia dan

20 Jesse H. Choper, Judicial Review and the National Political Process: a Funcional Reconsiderantion of the Role of the Supreme Court, (Chicago and London, the University of Chicago Press, 1980), hlm 4-5. Dikutp dari Janedjri M. Gaffar, Demokrasi Pemilu di Indonesia, (Jakarta:Konstitusi Press, 2013), hlm. 61.

21 Sofia Amaral-Garcia et. al., "Judicial Independence and Party Politics in the Kelsenian Constitutional Courts: The Case of Portugal', Journal of Empirical Legal Studies, Issue 2 Vol. 6, (2009), hlm. 387.

22 Ketika hak asasi manusia diimplementasikan dalam hukum internasional, kita masih menyebutnya sebagai hak asasi manusia, namun manakala itu diimplementasikan didalam hukum domestik, kita condong menggambarkannya sebagai hak sipil atau hak konstitusional." James W. Nickel, Making Sense of Human Rights Philosophical Reflection on the Universal Declaration of Human Right, Terjemah, Titis Eddy Arini, Hak Asasi Manusia: Refleksi Filosofis atau Deklarasi Universal Hak Asasi Manusia (Jakarta: Gramedia Pustaka Utama, 1996), hlm. 55. Dikutp dari Tim Penyusun Hukum Acara Mahkamah Konstitusi, Hukum Acara Mahkamah Konstitusi,cetakan pertama, (Jakarta: Sekertariat Jenderal Kepaniteraan MKRI, 2010), hlm. 113 
hak-hak warga negara, dapat dilihat dalam Pasal 27, Pasal 28 dan Pasal 29 UUD 1945. Secara kuantitas Pasal 28 UUD 1945 mencakup Pasal 28A sampai Pasal 28J, telah sangat akomodatif untuk mengakui dan menjamin hak-hak konstitusional warga negara yang kemudian dijelaskan lebih lanjut didalam UU MK..$^{23}$ Dalam Penjelasannya, Pasal 51 ayat (1) UU MK dijelaskan bahwa yang dimaksud dengan hak konstitusional adalah “... hak-hak yang diatur dalam Undang-Undang Dasar Negara Republik Indonesia Tahun 1945”.

Salah satu alasan munculnya ketentuan tersebut didalam konstitusi ialah terkait dengan ciri dari negara hukum (rechstaat/ rule of law) yakni adanya jaminan terhadap HAM. HAM merupakan unsur yang paling penting dan harus termuat dalam penyelenggaraan negara hukum. Sesuai dengan tata urut perundang-undangan sebagaimana dijelaskan dalam Pasal 7 Ayat (1) Undang-Undang Nomor 12 Tahun 2011 tentang Pembentukan Peraturan Perundang-Undangan, memiliki arti, HAM diatur dalam UUD 1945 sebagai sumber hukum pertama. Setiap peraturan hukum mempunyai kekuatan hukum atau daya berlaku sesuai hierarkinya atau tingkat kewenangannya, sehingga setiap peraturan hukum yang berlaku senantiasa bersumber pada peraturan hukum yang lebih tinggi tingkatannya. Ini berarti pula bahwa setiap peraturan hukum yang berlaku itu tidak boleh bertentangan dengan peraturan hukum yang lebih tinggi derajatnya atau dapat dikatakan materi muatan yang diatur dengan undang-undang berisi hal-hal yang mengatur lebih lanjut ketentuan UUD 1945, yang didalamnya termasuk HAM. ${ }^{24}$

Perlu ditegaskan disini, segala macam bentuk produk hukum disemua tingkat dilarang melanggar HAM sebagaimana dijamin oleh UUD 1945 itu. Disinilah fungsi MK Agar hak-hak fundamental warga negara tidak serta merta dilanggar atau disalahgunakan melalui UU atau bahkan sekalipun oleh penguasa. MK dapat membatalkan suatu peraturan perundang-undangan (dalam konteks ini UU) yang bertentangan dengan konstitusi, termasuk kedalam aspek HAM. Namun hal yang menjadi pokok permasalahan ialah, terbatas pada UU yang sudah secara sah saja yang bisa dibatalkan oleh MK, kemudian

23 Undang-Undang Nomor 8 Tahun 2011 Tentang Perubahan Atas Undang-Undang Nomor 24 Tahun 2003 Tentang Mahkamah Konstitusi.

24 Pasal 10 Undang-Undang Nomor 12 Tahun 2011 tentang Pembentukan Peraturan Perundang-Undangan. bagaimana dengan RUU yang terindikasi bisa mengancam hak konstitusional warga negara? Meskipun RUU secara an sich belum memiliki kekuatan hukum mengikat, namun yang perlu digarisbawahi ialah, jangan sampai produk hukum peraturan perundang-undangan yang dibuat hanya digunakan sebagai "bahan percobaan". Maksud penulis, ketika ada suatu RUU yang terindikasi akan melanggar hak konstitusional warga negara, kemudian UU tersebut disahkan, baru fungsi MK dapat dijalankan. Nah, persoalan tersebut yang oleh penulis sebut sebagai triall and error dalam prosesnya.

Gagasan terhadap mekanisme preventive review ke dalam ranah MK merupakan bagian dari upaya perlindungan terhadap hak-hak warga negara yang dilindungi oleh Konstitusi (UUD 1945). Setidaknya mekanisme ini dapat meminimalisir munculnya produk hukum peraturan perundang-undangan yang tidak sesuai dengan norma konstitusi sebagai penjamin hak konstitusi warga negara, karena kontitusionalitas suatu RUU akan di tinjau terlebih dahulu oleh MK sebagai pengawal konstitusi (the guardian of the constitution).

Ketiga, memberikan kepastian hukum. Didalam pembentukan peraturan perundangundangan, salah satu materi muatan yang harus diperhatikan dan di internalisasikan dalam merumuskan suatu norma ialah mencerminkan asas kepastian hukum. Asas ini bertujuan untuk menghindari adanya tumpang tindih terhadap undang-undang yang ada dibawahnya, serta menghindari adanya disharmonisasi dan multitafsir terhadap konstitusi. Sebagaimana Satjipto Rahardjo mengatakan "sicherkeit des Rechts selbst" (kepastian tentang hukum itu sendiri). empat hal yang menurutnya berhubungan dengan makna kepastian hukum. Pertama, bahwa hukum itu positif, artinya bahwa ia adalah perundangundangan (gesetzliches Recht). Kedua, bahwa hukum itu didasarkan pada fakta (Tatsachen), bukan suatu rumusan tentang penilaian yang nanti akan dilakukan oleh hakim, seperti "kemauan baik","kesopanan". Ketiga, bahwa fakta itu harus dirumuskan dengan cara yang jelas sehingga menghindari kekeliruan dalam pemaknaan, di samping juga mudah dijalankan. Keempat, hukum positif itu tidak boleh sering diubah-ubah..$^{25}$

25 Satjipto Rahardjo, Hukum Dalam Jagat Ketertiban, (Jakarta, UKI Press, 2006), hlm 135-136. 
Sehingga produk hukum yang demikian akan memberikan harmonisasi hukum yang menunjang satu sama lain.

Kepastian hukum ini bisa semakin terwujud apabila ada proses pre-view (baca: Preventive review) terlebih dahulu sebelum diimplementasikan, karena yang di-review merupakan norma hukum yang dibawah dengan norma hukum yang diatasnya (konstitusi), artinya pengujian ini merupakan pengujian konstitusional awal yang harapannya, UU yang dibuat tidak hanya UU yang "mengawang-awang" karena belum jelas status konstitusionalnya. Meskipun selama ini dalam pembuatan suatu produk hukum peraturan perundangan harus mencantumkan Naskah Akademik, yang didalamnya memuat tiga unsur yakni filosofis, yuridis dan sosiologis, namun tidak jarang produk yang dihasilkan jauh dari harapan konstitusi. Untuk itu proses preview melalui mekanisme preventive review ini ialah dalam rangka mmberikan kepastian hukum, sehingga produk hukum peraturan perundangundangan tidak mudah diubah ataupun dibatalkan keberlakuannya kedepan karena dianggap inconstitutional.

Keempat, mengurangi banyaknya produk hukum peraturan perundang-undangan yang diujikan. Banyak produk perundang-undangan kita yang berisi agenda-agenda tersembunyi dari pihak dan kelompok tertentu. Sehingga justru memicu gesekan dan konflik antar unsur bangsa serta menimbulkan kegaduhan diberbagai bidang. Tumpukan peraturan perundangan yang dibatalkan lewat judicial review oleh $\mathrm{MK}^{26}$, serta ribuan perda yang dibatalkan oleh depdagri ${ }^{27}$, menjadi

26 Sejak dibentuknya lembaga MK hingga saat ini, sebanyak 1920 perkara pengujian undang-undang telah ditangani. Lihat dalam $\mathrm{h} \mathrm{t} \mathrm{t} \mathrm{p} \mathrm{s} \mathrm{:} \mathrm{/} \mathrm{/} \mathrm{m} \mathrm{kri} \mathrm{i} \mathrm{d}$ / i n d e x . p h p ?page=web.RekapPUU\&menu=5 diakses pada 24 Maret 2019 Pukul 12.20 WIB.

27 Atau yang hari ini disebut dengan Kemendagri (Kementerian Dalam Negeri), pada tahun 2016 lalu, kemendagri membatalkan setidaknya 3.143 peraturan daerah termasuk didalamnya peraturan menteri. Tujuan dibatalkannya karena perda tersebut dinilai menghambat pertumbuhan ekonomi daerah. Lihat dalam $\mathrm{h} t \mathrm{t} \mathrm{p}: / / \mathrm{s}$ e t k a b . g o . i d /kemendagri-resmi-umumkan-3143-perda-yang-dibatalkan/, diakses pada 24 Maret 2019 Pukul 13.00 WIB. Namun saat ini kewenangan membatalkan perda ditingkat provinsi, kabupaten/kota tidak lagi menjadi ranah kewenangan kemendagri, ketentuan tersebut dapat dilihat dalam putusan MK Nomor 137/PUU-XIII/2015dan Putusan MK Nomor 56/PUU-XIV/2016, kini pembatalan perda berada di contoh nyata dari apa yang dikatakan diatas. ${ }^{28}$ Hal tersebut juga dapat dimaknai bahwa, secara kualitas produk hukum peraturan perundangundangan yang selama ini dibuat oleh lembaga pembentuk undang-undang patut dipertanyakan. Faktanya, selama ini produk hukum yang ada seringkali bertolak belakang dengan keteraturan hukum.

Diskurusus lebih lanjut dari persoalan diatas jika dipahami lebih seksama, dengan banyaknya peraturan perundang-undangan yang dibatalkan, akan berpengaruh penilaian masyarakat terhadap lembaga pembuat undang-undang, stigma yang muncul kemudian lembaga pembuat undangundang akan dinilai "tidak mampu" dalam membuat UU yang berkualitas. Jika mekanisme preventive review ini diterapkan, maka kemudian memberikan 2 makna, pertama, mengurangi kesan buruk dan menjaga integritas lembaga pembentuk undang-undang agar tidak dianggap melahirkan produk yang asal-asalan. Kedua, Setidaknya Melalui mekanisme preventive review, dapat meminimalisir banyak peraturan perundang-undangan yang diuji konstitusionalnya lebih lanjut oleh MK, karena sebelum disahkan dan diberlakukan suatu RUU disaring dan diuji kualitas konstitusionalnya.

Sehingga kedepan, produk hukum peraturan perundang-undangan tidak lagi banyak menumpuk di meja kerja MK, dan yang paling penting dari itu semua ialah, jika kualitas produk hukum peraturan perundang-undangan sudah baik, maka setidaknya langkah awal proses pembangunan nasional tidak akan terganggu.

Relevansi daripada produk hukum yang baik berpengaruh terhadap pembangunan nasional adalah apabila produk hukum tersebut berkesesuaian dengan kontitusi atau UUD 1945, yang merupakan arah dan pijakan pembangunan di Indonesia. Sebaliknya, tentu saja produk hukum yang buruk akan menghambat proses pembangunan itu sendiri, dapat dilihat di negara Indonesia yang sampai saat ini masih tertatih-tatih. Terkait pertanyaan, apa manfaat penerapan mekanisme preventive review terhadap pembangunan di Indonesia dapat di ilustrasikan dengan contoh analisa. Tulisan ini, akan memberikan contoh bagaimana produk hukum yang tidak baik,

ranah kewenangan MA

28 Yovita A. Mangesti \& Bernard L. Tanya, Moralitas Hukum, op.cit., hlm 20. 
berpengaruh/ menghambat terhadap proses pembangunan negara dengan merujuk analisa yang dilakukan oleh Hikmahanto Juwana, berangkat dari frasa "dikuasai oleh negara" dalam UUD 1945, disitu dijelaskan negara berhak penguasaan atas, cabang-cabang produksi yang penting bagi negara dan menguasai hidup orang banyak dikuasai oleh negara, ${ }^{29}$ serta bumi air dan kekayaan alam yang terkandug didalamnya dikuasai oleh negara dan dipergunakan untuk sebesar-besar kemakmuran rakyat. ${ }^{30}$ Jika ditelusuri lebih lanjut, tafsir dikuasai negara dimaknai berbeda dalam beberapa UU, misalnya dalam UU minyak dan gas bumi (migas) ${ }^{31}$ dan UU mineral dan batu bara (minerba) ${ }^{32}$. Menurut hikmahanto J, tafsir dikuasai "negara hanya" mengikuti "rezim yang bekuasa". Sehingga dalam beberapa UU dimaksudkan hanya menguntungkan bagi kalangan tertentu. ${ }^{33}$

Uraian diatas, dapat dilihat bahwa, tafsir terhadap istilah dalam konstitusi dapat dikatakan hanya atas nama kepentingan kelompok tertentu sehingga berdampak pada meminggirkan kesejahteraan rakyat, padahal UU yang dibuat tentunya harus mencerminkan kepentingan dan kesejahteraan masyarakat, bukan untuk sekelompok orang atau kalangan tertentu. Untuk itu pengujian RUU menjadi hal penting, melalui preventive

29 Pasal 33 ayat (2) UUD Negara Republik Indonesia Tahun 1945 (Pasca Amandemen).

30 Pasal 33 ayat (3) UUD Negara Republik Indonesia Tahun 1945 (Pasca Amandemen).

31 Dalam U No. 44 Prp. Tahun 1960 Tentang Pertambangan Minyak dan Gas Bumi ( selanjutna disebut, UU Migas 1960) berbeda dengan UU Nomor 22 Tahun 2001 Tentang Minyak dan Gas Bumi (selanjutnya disebut, UU Migas 2001) yang pada dasarnya negara (pemerintah) memiliki perbedaan interpretasi terhadap istilah dikuasai negara Pasal 33 UUD 1945.

32 Sedangkan dalam bidang minerba, dapat merujuk pada UU Nomor 11 Tahun 1967 Tentang Ketentuanketentuan Pokok Pertambangan (seanjutnya disebut, UU pertambangan Umum Tahun 1967) dikenal dengan kontrak dan kuasa pertambangan. Sedangkan, ada perbedaan dalam UU Nomor 4 Tahun 2009 Tentang Pertambanga Mineral Dan Batubara (selanjutnya disebut, UU Minerba Tahun 2009), yakni mendasarkan pada rezim izin. Satu hal yang perlu dicatat, instansi pemerintah yang punya peran sentral adalah pemerintah pusat, berbeda dengan UU Minerba 2009, yang mendasarkan rezim izin, dan izin pun tidak dominan dikeluarkan oleh pemerintah pusat, tetapi oleh pemerintah daerah.

33 Analisa lebih lanjut Prof. Hikmahanto Juwana dapat dilihat dalam kolom Opini Koran Kompas, dengan Judul "Ikhwal Dikuasai Negara", edisi 3 September 2015 review setidaknya bisa memfilter RUU yang terindikasi tidak sesuai dengan kebutuhan negara dan bertententangan dengan konstitusi. Kedepan, produk hukum yang dibuat tidak semena-mena dapat ditegakkan, namun memang mencerminkan kebutuhan masyarakat yang diwakili oleh negara.

\section{Membaca Peluang Penerapan Mekanisme Preventive Review di Indonesia}

Berangkat dari hipotesa sebagaimana telah diuraikan diatas, menerapkan lebih lanjut mekanisme preventive review didalam kewenangan MK menjadi urgen untuk saat ini, yang mana model preventive review pada dasarnya merupakan suatu mekanisme yang dapat dijumpai dalam dunia peradilan konstitusi. Secara global, Mekanisme preventive review ini telah banyak diterapkan di berbagai negara antara lain Austria, Hungaria, Afrika Selatan, Belgia dan Prancis. ${ }^{34}$ Lahirnya peradilan konstitusi di negara eropa didirikan dibeberapa negara-negara pasca otoriter, sedangkan mekanisme preventive review pertama kali diterapkan oleh negara perancis dan Belgia. Hal ini ditegaskan Oleh Lech Garlicki ${ }^{35}$ dengan menyatakan

"France and Belgium present the only examples of constitutional jurisdictions that were not established as one of an array of democratization devices. But both of those jurisdictions are hardly typical: the Conseil Constitutionnel emerged in the rather particular context of the beginnings of the Fifth Republic and primarily undertakes preventive review; the Cour d'Arbitrage emerged from the equally distinctive process of Belgian regionalization."

Artinya, mekanisme yang demikian memiliki peluang untuk dapat diterapkan dalam sistem ketatanegaraan Indonesia. Terkait badan mana yang akan menerapkan mekanisme preventive review, sekiranya dapat mencontoh pada negara lain yang lebih dulu menerapkannya dalam sistem ketatanegaraan dengan memberikan kewenangan ini kepada lembaga peradilan konstitusi seperti di negara Austria, atau membentuk badan tersendiri diluar lembaga peradilan konstitusi yang sudah ada. Sebagai pembanding, ada beberapa tulisan

34 Disimpulkan dalam, Jimly Asshiddiqie dan Ahmad Syahrizal, Peradilan Konstitusi Di 10 Negara, (Jakarta: Sinar Grafika, 2012) hlm. 10, 20, 192, 275-276, 137.

35 Lech Garlicki, "Constitutional Courts Versus Supreme Courts", Oxford University Press and New York University School of Law, I.con, No 1 Vol 5, (2007), hlm 64 . 
yang mendorong mekanisme preventive review ini layak diterapkan dalam sistem ketatanegaraan Indonesia, artinya, mekanisme ini terbukti berhasil "mencuri perhatian" oleh para akademisi atas dasar keinginan memperkuat sistem penyelenggaraan negara yang baik serta keinginan melahirkan produk hukum peraturan perundang-undangan yang bermutu, tentu dengan sudut pandangnya masing-masing, termasuk penulis.

Artikel yang ditulis oleh Muhammad Reza Maulana, dengan judul "Upaya Menciptakan Produk Hukum Berkualitas Konstitusi Melalui Model Preventif Review". Dalam artikel tersebut, rekomendasi yang diberikan oleh sang penulis agar kewenangan mekanisme preventive review tetap diberikan oleh lembaga MK dengan alur sebagaimana mestinya dalam proses pembuatan dan pembahasan pembentukan UU, namun ditambahkan satu alur lagi sebelum mendapat persetujuan oleh Presiden.

“...Alur sebuah undang-undang sebagaimana tersebut di atas $^{36}$, kiranya dapat ditambah dengan bagian, setelah rancangan undang-undang kemudian disetujui untuk ditetapkan dan dibahas dalam rapat paripurna, maka pembahasannya kemudian disepakati baik melalui musyawarah maupun voting, dan sebelum kemudian DPR menyampaikan hasil pembahasan yang telah disepakati oleh DPR kepada Presiden untuk disahkan dan dilembarnegarakan, maka Mahkamah Konstitusi kiranya dapat menjadi penengah diantara dua proses tersebut, dimana setelah pembahasan rancangan undangundang dinyatakan selesai, maka DPR sebelum menyampaikan hasil pembahasan kepada Presiden untuk ditandatangani, menyampaikan hasil pembahasan tersebut kepada Mahkamah Konstitusi untuk diteliti dan diberikan keputusan hukum terhadapnya...". ${ }^{37}$ Menurutnya, mekanisme demikian mirip model impeachment presiden dan wakil presiden.

Penelitian yang tidak kalah menarik terkait persoalan ini, dikaji oleh Manunggal K. Wardaya, dengan Judul "Constitutional Preview sebagai Upaya Menciptakan Perundangan Yang Efisien dan Berkeadilan". ${ }^{38}$ Rekomendasi yang diberikan oleh

36 Lihat, Muhammad Reza Maulana, Upaya... op.cit, hlm 791-792.

37 Muhammad Reza Maulana, Upaya... op.cit, hlm 791792.

38 Oleh sang penulis, istilah yang digunakan dalam hal pengujian konstitusionalitas RUU ini dengan menggunakan istilah Constitutional preview. Lihat sang penulis, apabila mekanisme constitutional preview (baca: Preventive review) ini diadopsi dalam sistem ketatanegaraan Indonesia ialah membentuk lembaga baru dengan mengadopsi praktik yang ada di negara perancis.

"...Dibebentuk dewan ataupun komisi konstitusi untuk melakukan kewenangan ini. Dewan atau komisi inilah yang nantinya akan memiliki kewenangan konstitusional untuk melakukan penilaian atas muatan suatu RUU. Dewan atau komisi ini akan memiliki kewenangan khusus melakukan penilaian ataupun uji konstitusionalitas suatu RUU..". ${ }^{39}$

Kiranya sudah sangat luas kontribusi pemikiran yang diberikan oleh para peneliti diatas. Setidaknya berhasil memberikan gambaran bagaimana jika suatu saat, mekanisme preventive review ini akan diterapkan di Negara Indonesia. Penulis dalam hal ini juga memiliki konsep yang tidak jauh berbeda untuk mendorong mekanisme ini agar tetap diadopsi dalam sistem ketatanegaraan Indonesia. sebagai upaya memberikan kontribusi pemikiran yang progresif. Penulis mendorong agar mekanisme preventive review diatur dalam kewenangan MK dengan memberikan perluasan terhadap kewenangannya, yang semula ada 4 kewenangan dan 1 kewajiban, apabila mekanisme ini diterapkan maka 1 kewenangan ini harus diakomodir dalam UUD. Namun yang menjadi persoalan saat ini ialah, minimnya jumlah hakim pada MK yang hanya beranggotakan 9 orang hakim tentunya akan membuat lembaga ini menjadi kewalahan.

Upaya yang paling mungkin dilakukan ialah dengan membuat kamar/forum tersendiri namun tetap menginduk pada MK. Yang nantinya akan diisi oleh para hakim konstitusi yang khusus membidani praktik ini, sehingga tidak menganggu hakim konstitusi yang bertugas melayani 4 kewenangan dan 1 kewajiban pokoknya. Juga bisa ditambah dengan dihadirkan para akademisi dalam berbagai bidang untuk didengar pendapat dan keterangannya. Kamar ini-lah yang nantinya akan membidani tugas penilaian materi muatan suatu rancangan undangundang.

Dalam hal hasil penilaian/ pengujian (atau apapun nanti istilah yang digunakan) RUU ini dalam Wardaya, Manunggal K. Constitutional Preview sebagai Upaya Menciptakan Perundangan Yang Efisien dan Berkeadilan, makalah disampaikanpada konferensi Nasional Hukum Tata Negara (KNHTN) ke-4, Jember, 10-13 November 2017.

39 Ibid. tanpa hlm. 
dapat merujuk analisa Manunggal K. Wardaya, dapat bersifat layaknya putusan MK yang mengikat, atau dapat juga seperti rekomendasi. Jika bersifat mengikat, secara logis DPR dan Presiden sebagai lembaga negara yang berwenang membat perundang-undangan wajib mematuhi Putusan penilaian/ pengujian ini dan wajib untuk membahas ulang RUU yang bersangkutan dengan segala konsekuensinya. Jika demikian, keharusan untuk menjadikan putusan badan ini mengikat berpotensi menjadikannya superior dari badan pembentuk dan pembahas UU yakni DPR dan Presiden yang dipilih secara demokratis oleh rakyat. ${ }^{40}$ Lebih lanjut, Jika hal ini menjadi kekhawatiran, maka dapat saja ditentukan nantinya bahwa putusan badan ini bersifat rekomendatif yang tidak mengikat. DPR dan Presiden akan mendapatkan rekomendasi terkait klausul maupun bagian dalam suatu RUU yang dinilai berpotensi melanggar konstitusi. Adapun pelaksanannya terpulang pada DPR dan Presiden apakah akan melaksanakan rekomendasi ataukah tidak. ${ }^{41}$ Terlepas dari akankah para pembuat UU tidak mematuhi isi dari rekomendasi tersebut, setidaknya dapat menjadi pedoman bagi masyarakat untuk mengetahui isi substansi materi suatu RUU yang bersangkutan jika diterapkan nantinya dan dapat menjadi pegangan mengajukan judicial review ke MK, jika memang UU yang bersangkutan tidak sesuai yang diharapkan.

Mengingat urgensi kehadiran produk hukum yang berkualitas dan bermutu sangat mendesak, selayaknya mekanisme ini diterapkan di Indonesia. Soal konsep praktisnya beberapa usulan yang sudah disinggung diatas setidaknya memberikan pandangan bagi $\mathrm{MPR}^{42}$, untuk urun rembug membahas lebih lanjut.

40 Lihat dalam Wardaya, Manunggal K. Constitutional Preview... op.cit.

41 Lihat dalam Wardaya, Manunggal K. Constitutional Preview... op.cit.

42 Sebagai badan yang berwenang melakukan perubahan terhadap UUD Negara kesatuan Republik Indonesia, perlu untuk melakukan kajian lebih lanjut mengenai kemungkinan ide penerapan mekanisme preventive review dalam sistem ketatanegaraan. Hal demikian diharapkan menjadi suatu kewajaran sebagai bentuk ikhtiar semata-mata ingin memperkuat sistem ketatanegaraan serta keinginan untuk melahirkan produk-produk hukum yang berkualitas dan bermutu guna menunjang pembangunan nasional di negara Indonesia.

\section{Kesimpulan}

Upaya mewujudkan peningkatan pembangunan nasional dapat dilakukan melalui peningkatan kualitas produk hukum peraturan perundang-undangan. Hal tersebut dapat di inisiasi melalui penambahan kewenangan baru pada Mahkamah Konstitusi untuk melakukan preventive review pada setiap rancangan undang-undang sebelum rancangan undang-undang tersebut disahkan atau diberlakukan. Selain itu, terdapat urgensi penambahan kewenangan preventive review didalam kewenangan MK, setidaknya ada empat aspek pertimbangan, pertama, sebagai bentuk pencegahan adanya undang-undang yang tidak berkualitas. Kedua, sebagai bentuk dari perlindungan terhadap hak-hak konstitusional warga negara. Ketiga, memberikan kepastian hukum. Keempat, mengurangi banyaknya produk hukum peraturan perundang-undangan yang diujikan.

Model pengujian preventive riview ini dipandang penting untuk diterapkan di Indonesia sebagai upaya preventif legislasi yang buruk yang akanmenggangguprosesberjalannyapembangunan di Indonesia dalam segala aspek. Mekanisme ini dapat diterapkan dalam sistem peradilan konstitusi di Indonesia dengan menambahkan kewenangan baru, atau dapat dibuat forum tersendiri dalam kamar MK dengan komposisi hakim konstitusi yang lain dengan hakim konstitusi yang menangani 4 (empat) kewenangan dan 1 (satu) kewajiban pokoknya. Artinya, penambahan personil hakim konstitusi dikhususkan untuk menangani praktik preventive review, dalam hal hasil penilaian RUU nanti, dapat bersifat layaknya putusan MK yang memiliki sifat mengikat (binding), atupun hanya bersifat rekomendatif, artinya keputusan akan dilaksanakan atau tidaknya hasil penilaian RUU melalui mekanisme preventive riview ini, terpulang kepada lembaga pembuat undang-undang yakni DPR dan Presiden.

\section{Daftar Pustaka}

Buku

Asshiddiqie, Jimly, Konstitusi dan konstitusionalisme, Cetakan Keempat. Jakarta: Sinar Grafika, 2017. 
Asshiddiqie, Jimly dan Ahmad Syahrizal, Peradilan Konstitusi di 10 Negara. Jakarta: Sinar Grafika, 2012.

Arini, Titis Eddy, Hak Asasi Manusia: Refleksi Filosofis atau Deklarasi Universal Hak Asasi Manusia. Jakarta: Gramedia Pustaka Utama, 1996.

Black, Donald, The Behaviour of Law. New York: Academic Press, USA, 1976.

Choper, Jesse H., Judicial Review and the National Political Process: a Funcional Reconsiderantion of the Role of the Supreme Court. London: The University of Chicago Press, 1980.

Gaffar, Janedjri M., Demokrasi Pemilu di Indonesia. Jakarta: Konstitusi Press, 2013.

Hakim, Abdul Aziz, Negara Hukum Dan Demokrasi di Indonesi. Yogyakarta: Pustaka Pelajar, 2011.

Mujahidin, Ahmad, Peradilan Satu Atap di Indonesia. Bandung: Refika Aditama, 2007.

Mahmuzar, Sistem Pemerintahan Indonesia Menurut UUD 45 Sebelum dan Sesudah Amandemen. Bandung: Nusa Media, 2014.

Nasution, Bahder Johan, Negara Hukum dan Hak Asasi Manusia. Bandung: Mandar Maju, 2013.

Huda, Ni'matul, Ilmu Negara, Jakarta: Rajawali Press, 2013.

Kusumaatmadja, Mochtar, Fungsi Dan Perkembangan Hukum Dalam Pembangunan Nasional. Lembaga Penelitian Hukum, dan Kriminologi, Fakultas Hukum Universitas Padjadjaran, Bandung: Penerbit Binacipta, 1970.

Mangesti, Yovita A. \& Bernard L. Tanya, Moralitas Hukum, cetakan pertama, Yogyakarta: Genta Publishing, 2014.

Moh. Mahfud MD, Politik Hukum di Indonesia. cetakan kedua, Jakarta: PT Pustaka LP3ES, 2001.

Rahardjo, Satjipto, Hukum Dalam Jagat Ketertiban. Jakarta: UKI Press, 2006.

Sunarmi, Membangun Sistem Peradilan di Indonesia. Medan: e-USU Respository,
2004.

Sekretariat Jenderal Majelis Permusyawaratan Rakyat Republik Indonesia, Panduan Pemasyarakatan Undang Undang Dasar Negara Republik Indonesia Tahun 1945 dan Ketetapan Majelis Permusyawaratan Rakyat republik Indonesia. Jakarta: Sekretariat Jenderal MPR RI, 2012.

Tim Penyusun Hukum Acara Mahkamah Konstitusi, Hukum Acara Mahkamah Konstitusi,cetakan pertama, Jakarta: Sekertariat Jenderal Kepaniteraan MKRI, 2010 .

\section{Karya Ilmiah Dan Surat Kabar}

Collins, Dan Josua Satria dan Pan Mohammad Faiz. "Penambahan Kewenangan Constitutional Question Di Mahkamah Konstitusi Sebagai Upaya Untuk Melindungi HakHak Konstitusional Warga Negara”, Jurnal Konstitusi, No 4 Vol 15, ( 2018): 689-709.

Garcia, Sofia Amaral, Nuno M. Garoupa and Veronica Grembi. "Judicial Independence and Party Politics in the Kelsenian Constitutional Courts: The Case of Portugal", Journal of Empirical Legal Studies, Issue 2 Vol. 6, (2009): 381-404.

Garlicki, Lech. "Constitutional Courts Versus Supreme Courts", Oxford University Press and New York University School of Law, Journal I.con, No 1 Vol 5, (2007): 44- 68.

Maulana, Muhammad Reza. "Upaya menciptakan Produk Hukum Berkualitas Kontitusi Melalui Model Preventif Review", Jurnal Konstitusi, No 4 Vol. 15, (2018): 775- 795.

Rahardjo, Satjipto. Teori dan Metode dalam Sosiologi Hukum, Makalah Disampaikan pada Pertemuan Ilmiah, Fakultas Hukum UII Yogyakarta, 11-12 November 1984. (tanpa halaman).

Wardaya, Manunggal K. "Constitutional Preview sebagai Upaya Menciptakan Perundangan Yang Efisien dan Berkeadilan", Makalah Disampaikan pada Konferensi Nasional Hukum Tata Negara (KNHTN) ke-4, Jember, 10-13 November 2017, (tanpa halaman). 
Menggagas Mekanisme Preventive Review...

Hikmahanto Juwana, Ikhwal Dikuasai Negara, Kompas, edisi 3 september 2015.

\section{Undang-Undang}

Undang-Undang Dasar Negara Republik Indonesia Tahun 1945 (Pasca Amandemen).

Undang-Undang Nomor 8 Tahun 2011 Tentang Perubahan Atas Undang-Undang Nomor 24 Tahun 2003 Tentang Mahkamah Konstitusi.

Undang-Undang Nomor 12 Tahun 2011 tentang Pembentukan Peraturan PerundangUndangan.

\section{Internet}

MK RI, Rekapitulasi Perkara Pengujian UndangUndang.

https://mkri.id/index.php?page=web. RekapPUU\&menu $=5$ (diakses pada 24 Maret 2019).

Setkab RI, Kemendagri Resmi Umumkan 3.143 Perda Yang Dibatalkan.

h t t p : / / s e t k a b.g o . i d /kemendagri-resmiumumkan-3-143-perda-yang-dibatalkan/ (diakses pada 24 Maret 2019). 